\begin{tabular}{|c|c|c|c|c|c|}
\hline 丸山 勝也 ${ }^{1)}$ & 岡崎 & 勲" & 和田 & 則仁 ${ }^{2)}$ & 高橋 \\
\hline 奥山 啓二11 & 横山 & 顕" & 中野 & 雅行 ${ }^{3)}$ & 石井 \\
\hline
\end{tabular}

\begin{abstract}
要 旨：肝生検を施行し得た $\mathrm{HBs}$ 抗原, $\mathrm{HCV}$ 抗体共に陰性の各種アルコール性肝疾患患者を 対象として, 肝生検時の血清ヒト肝細胞增殖因子 (hHGF) を測定した.アルコール性肝疾患患 者全体および, 症例数の少ない脂肪肝, アルコール性肝炎を除く各種肝疾患群において, 文献 上の健常群と比較して有意な高值を示した。 また肝硬変症では脂肪肝を除くすべての疾患群に 比し有意な高值を示した。血清 $\mathrm{hHGF}$ 值は肝の組織学的所見のうち肝線維化の程度とのみ良好 な相関を示した。さらに血清 hHGF 值は, アルブミンやコリンエステラーゼの他にIV型コラー ゲン, ラミニンなどの肝線維化を表す検査值と良好な正の相関を示した.

血清 hHGF 值は断酒後低下したが, それそれの時点でも肝線維化の程度や血清線維化マー カーであるラミニン値と有意な相関を示した. 血清 hHGF 值は肝線維化と何らかの関連を示し ているものと推測された.
\end{abstract}

索引用語： ヒト肝細胞增殖因子 (hHGF) アルコール性肝疾患＼cjkstart肝線維化 線維化マーカー 肝組織

\section{はじめに}

1967年 Moolton ら”は部分肝切除ラットの血液中 に肝再生を促進させる因子を発見した. さらに1985年 に坪内らによって同様の肝緇胞を増殖させる因子が, 劇症肝炎患者血清中に見い出され文，上卜肝細胞増殖 因子 (hHGF) と命名された hHGF の測定法が開発され, 各種肝疾患で測定された 結果, 劇症肝炎の診断に有用として注目された占,. ま た hHGF の測定法も改良され7), 各種肝疾患患者血清 で検討され，健常人に比し高值を示すことが報告され ている゙. しかし，アルコール性肝疾患患者での検討や 肝の線維化の程度などの肝組織所見との対比について の報告はみられない.そこで著者らは肝生検を施行し 得た各種アルコール性肝疾患患者血清中の hHGFを
測定し, 肝生検の組織学的所見と対比し, 肝線維化の 程度と有意な正の相関を得たので報告する。

\section{対象および方法}

\section{対 象}

国立療養所久里浜病院にアルコール依存症の治療の 目的で入院し, 肝機能障害の診断のため肝生検を施行 し得た患者のうち, HBs 抗原陰性, HCV 抗体(第二世 代）陰性の49例を対象とした。

\section{血液検查法}

採血は肝生検当日早朝空腹時に行った。49例のうち 10 例はこの他入院後 $0,2,4,8$ 週にも採血を行っ た. 血清はー $30^{\circ} \mathrm{C}$ 以下に保存し, 測定時融解して使用 した. 血清 hHGF の測定は大塚アッセイ研究所の HGF 測定キットを用いて測定した。測定の原理は三

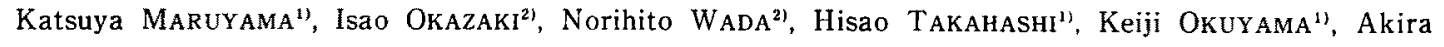
YoKoYAMA ${ }^{1)}$, Masayuki NAKANO ${ }^{31}$ and Hiromasa ISHII ${ }^{4}$

1）国立療苜所久里浜病院臨床研究部・内科

2) 東海大学医学部地域保健学

3）千㷊大学真核微生物学研究センター

4）慶應義塾大学医学部消化器内科

<受付日1995年 3月 9 日 $>$ 
段階のサンドイッチ ELISA 系である7). 血清IV型コ ラーゲンの測定は富士薬品工業社製の測定キット (IVEIA）および日本 DPC 社製の測定キット（7S-RIA）に よった，血清ラミニンの測定は富土薬品工業社製の測 定キット（LM-EIA）とへキスト社製の測定キット (LM-RIA)により行った. 血清III型プロコラーダンペ プチド (PIIIP) の測定はへキスト社製, 血清ヒアルロ ン酸 (HA) の測定は中外社製, 血清糖鎖欠損トランス フェリン (CDT) の測定はカビファルマシア社製の測 定キットにより行った.生化学的検査は日立703型自動 分析機により行った。末梢血血算は東亜医用電子 $\mathrm{E}$ 3000により測定した.

\section{肝の組織学的所見}

肝生検は症例により異なるが，入院後 $2 \sim 4$ 週目に 行った. 肝生検にて得た肝組織は $10 \%$ ホルマリン水溶 液で固定し,アルコール水溶液で型通りの脱水後パラ フィンに包埋し， $4 \mu \mathrm{m}$ の切片を作製した．通常の $\mathrm{H} ・$ $\mathrm{E}$ 染色の他，膠原線維はアザン・マロリ一染色を施し， 組織像を観察した．組織診断は文部省科学研究費総合 研究班（高田班）のアルコール性肝障害の診断基準に 則り行い ${ }^{9)}$, 壊死・炎症 (picemeal necrosis, lobular inflammation, portal tracts inflammation) p線維 化の程度は Knodell10)の HAI スコアーの基準に一部 改変を加え, 各群の中間の程度の所見がある場合は, 0.5を加える変法で評価した. また間質の変化であるア ルコールによる独特の線維化 (dense fibrosis) ${ }^{11}$ につ いても検討を加えた。組織診断名としては非特異的変 化 (NSR), 脂肪肝 (FL), 大酒家にみられる慢性肝炎 (CH), アルコール性肝炎 (AH), 肝線維症 (LF), 肝 硬変症 (LC) に分類した. Knodell の肝線維化のスコ アーは, 0 : no fibrosis, $0.5:$ very mild, 1 : mild, 2 : moderate, 3 : severe, 4 : cirrhosis に分類し, dense fibrosisについては線維化が全体にどの程度の 割合でみられるかにより, 1：1/4以下, $2: 1 / 4 〜 1 / 2$, $3: 1 / 2 \sim 3 / 4,4: 3 / 4$ 以上とした.

\section{統計学的解析}

数値は平均 \pm SD で表し, 統計学的有意差の検定は, 分散分析により行った。

\section{結 果 \\ 1. 各種アルコール性肝疾患患者における肝生検時 血清 hHGF 值}

アルコール性肝疾患全体では $0.31 \pm 0.13 \mathrm{ng} / \mathrm{m} l$ $(n=49)$ と, 文献上 ${ }^{3)}$ の健常群 : $0.20 \pm 0.07(n=957)$ と比較し，有意 $(\mathrm{p}<0.001)$ な高值を示した. 各種疾
患別では, 非特異的変化 $(\mathrm{NSR}): 0.25 \pm 0.07(\mathrm{n}=9)$ $(\mathrm{p}<0.05)$, 脂肪肝 $(\mathrm{FL}): 0.30,0.30(\mathrm{n}=2)$, 大酒 家にみられる慢性肝炎 $(\mathrm{CH}): 0.26 \pm 0.06(\mathrm{n}=6) （ \mathrm{p}<$ $0.05)$, アルコール性肝炎 (AH) : $0.24 \pm 0.08(\mathrm{n}=3)$, 肝線維症 (LF) : $0.31 \pm 0.06(\mathrm{n}=21)(\mathrm{p}<0.001)$, 肝 硬変症 $(\mathrm{LC}): 0.46 \pm 0.21(\mathrm{n}=9)(\mathrm{p}<0.001)$ と, 症 例数の少ない $\mathrm{FL}, \mathrm{AH}$ を除いて健常群に比し有意な 高值を示した．また LC は例数の少ない FLを除くす べての疾患群に比し有意 $(\mathrm{p}<0.05)$ な高値を示した (Fig. 1).

健常群の平均 $+2 \mathrm{SD}$ 以上を異常高値とすると 0.35 $\mathrm{ng} / \mathrm{m} l$ 以上となり, 各種疾患別の異常高值率は NSR : $2 / 9(22 \%)$, FL : 0/2( $0 \%)$, CH : 1/5(20\%), AH : $1 / 3$ (33\%), LF : 4/21 (19\%), LC : $5 / 9$ (56\%) であり，LCのみが比較的高い異常高值率であったが, アルコール性肝疾患全体では $13 / 49(26.5 \%)$ と低かっ た.

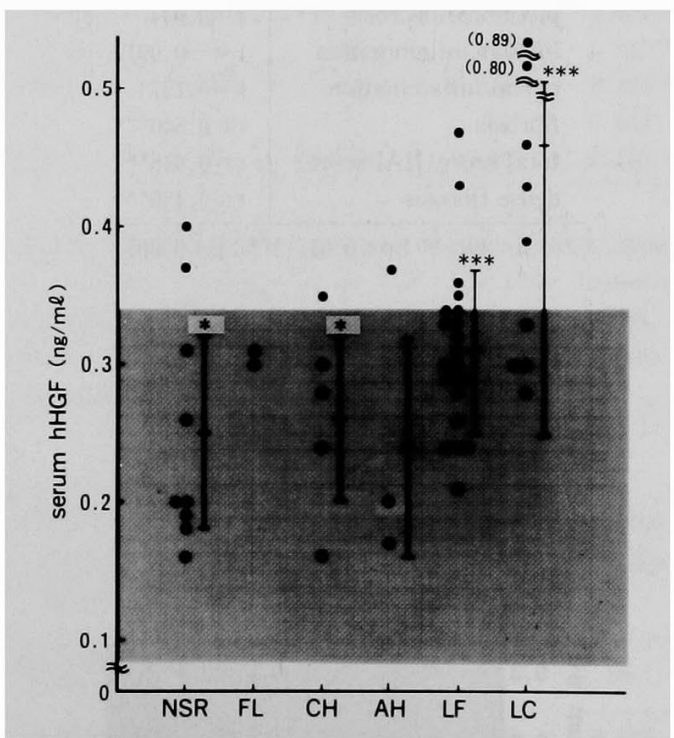

Fig. 1 Serum hHGF on biopsy day in patients with various alcoholic liver diseases. All kinds of alcoholic liver diseases except FL and $\mathrm{AH}$ show significantly high value compared to controls. Shadow area shows normal range (mean $\pm 2 \mathrm{SD}$ ). $* \mathrm{p}<0.05, * * *: \mathrm{p}<0.001$ compared to controls.

NSR: nonspecific reactive change, FL: fatty liver, $\mathrm{CH}$ : alcoholic chronic hepatitis, AH : alcoholic hepatitis, LF : liver fibrosis, LC: liver cirrhosis 


\section{2. 肝生検時血清 hHGF 值と肝の組織学的所見との 相関}

血清 hHGF 值と各種組織学的所見のスコアーとの 相関については, piecemeal necrosis : $r=0.044 （ n=$ 49), lobular inflammation: $r=-0.091 \quad(n=49)$, portal tracts inflammation: $r=0.157 \quad(n=49)$, fibrosis : $r=0.540(n=49) \quad(p<0.001) \quad($ Fig. 2), total score (HAI score) $: r=0.448 \quad(n=49) \quad(p<0.01)$, dense fibrosis: $r=0.442(n=49)(p<0.01)$ と, Knodell の線維化のスコアー, total score(HAI score) および dense fibrosis の程度との間に有意な相関を認 めた. しかし肝細胞の壊死，細胞浸潤の程度との間に は有意な相関を認めなかった（Table 1, Fig. 2)。

Table 1 Correlation between serum levels of $\mathrm{hHGF}$ and degree of various histological findings.

\begin{tabular}{l|l}
\hline \multicolumn{1}{c|}{ Histological findings } & $\begin{array}{l}\text { Correlation } \\
\text { efficiency }\end{array}$ \\
\hline piecemeal necrosis & $\mathrm{r}=0.044$ \\
lobular inflammation & $\mathrm{r}=-0.091$ \\
portal inflammation & $\mathrm{r}=0.157$ \\
fibrosis & $\mathrm{r}=0.540^{* * *}$ \\
total score(HAI score) & $\mathrm{r}=0.448^{* *}$ \\
dense fibrosis & $\mathrm{r}=0.433^{* *}$ \\
\hline \multicolumn{2}{c}{$\mathrm{n}=49, * *: \mathrm{p}<0.01, * * *: \mathrm{p}<0.001$}
\end{tabular}

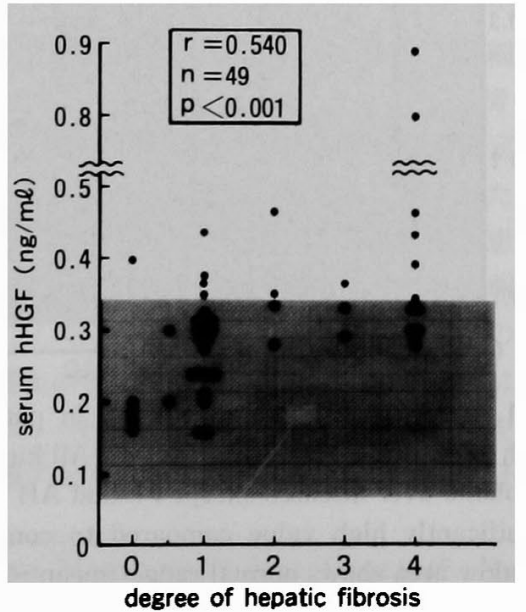

Fig. 2 Correlation between serum levels of hHGF on biopsy day and degree of hepatic fibrosis in patients with alcoholic liver disease. Degree of hepatic fibrosis is explained in the "text". Shadow area shows normal range (mean $\pm 2 S D$ ).

\section{3. 肝生検時血清 hHGF 値と各種血液検査成績との 相関}

Table 2 に示す如く血清 hHGF 值と血清IV 型コ ラーゲン (IV-EIA), 血清ラミニン (LM-EIA) などの 肝線維化マーカー値, それに各種生化学検查値, 末梢 血血算值との相関を検討したところ，最も良好な相関 を示したのは, LM-EIA : $r=0.614(n=41)(p<0.001)$ で, 次に血清蛋白分画のアルブミン $(\%): r=-$ $0.603(n=49) \quad(p<0.001)$ と $\gamma$-グロブリン $(\%): r=$ $0.603(n=49) \quad(p<0.001)$, ZTT $: r=0.576 \quad(n=49)$ $(\mathrm{p}<0.001)$, IV-EIA : $r=0.546(n=41) \quad(\mathrm{p}<0.001)$ がつづき,さらに $\mathrm{A} / \mathrm{G}: \mathrm{r}=-0.440(\mathrm{n}=49)(\mathrm{p}<$ $0.01)$, ALP: $r=0.387(n=49) \quad(p<0.01)$, Ch. E. $r=-0.385(n=49)(p<0.01), B U N: r=-0.325(n=$ 49) $(p<0.05)$, D. Bil. : $r=0.297(n=49) \quad(p<0.05)$ の順で有意な相関を示したが, GOT, GPT, $\boldsymbol{\gamma}$-GTP な どの血清酵素や，T.P., T.C., Plt. などの肝機能検査 とは有意な相関が認められなかった（Table 2)。

Table 2 Correlation between serum levels of hHGF and those of various blood tests.

\begin{tabular}{|c|c|c|c|}
\hline Blood test & $\begin{array}{l}\text { Correlation } \\
\text { efficiency }\end{array}$ & Blood test & $\begin{array}{c}\text { Correlation } \\
\text { efficiency }\end{array}$ \\
\hline IV-EIA \# & $\mathrm{r}=0.546^{* * *}$ & BUN & $\mathrm{r}=-0.325^{*}$ \\
\hline LM-EIA \# & $\mathrm{r}=0.614^{* * *}$ & Creat. & $\mathrm{r}=-0.083$ \\
\hline T.P. & $r=0.256$ & $\mathrm{CPK}$ & $r=0.143$ \\
\hline Alb. $(\mathrm{d} / l)$ & $\mathrm{r}=-0.257$ & $\mathrm{Na}$ & $r=-0.044$ \\
\hline $\mathrm{A} / \mathrm{G}$ & $r=-0.440^{* *}$ & K & $r=-0.000$ \\
\hline $\mathrm{ZTT}$ & $r=0.576^{* * *}$ & $\mathrm{Cl}$ & $r=-0.017$ \\
\hline T. Bil. & $r=0.177$ & $\mathrm{Ca}$ & $\mathrm{r}=-0.215$ \\
\hline D. Bil. & $\mathrm{r}=0.297^{*}$ & FBS & $\mathrm{r}=0.220$ \\
\hline GOT & $\mathrm{r}=0.231$ & Alb. $(\%)$ & $\mathrm{r}=-0.603^{* * *}$ \\
\hline GPT & $r=-0.026$ & $\alpha_{1}$-glob. (\%) & $\mathrm{r}=-0.123$ \\
\hline $\mathrm{LDH}$ & $r=0.074$ & $\alpha_{2}$-glob. (\%) & $r=0.016$ \\
\hline ALP & $\mathrm{r}=0.387^{* *}$ & $\beta$-glob. (\%) & $\mathrm{r}=0.262$ \\
\hline $\boldsymbol{\gamma}$-GTP & $r=0.175$ & $\gamma$-glob. $(\%)$ & $r=0.603^{* * *}$ \\
\hline Ch. E. & $\mathrm{r}=-0.385^{* *}$ & WBC & $r=0.036$ \\
\hline AMY & $\mathrm{r}=0.240$ & $\mathrm{RBC}$ & $r=-0.072$ \\
\hline T.G. & $r=0.007$ & $\mathrm{Hb}$. & $r=0.073$ \\
\hline T.C. & $\mathrm{r}=-0.259$ & Ht. & $r=0.052$ \\
\hline UA & $r=-0.047$ & Plt. & $r=-0.193$ \\
\hline
\end{tabular}

$\mathrm{n}=49(\#: \mathrm{n}=41)^{*}: \mathrm{p}<0.05,{ }^{* *}: \mathrm{p}<0.01,{ }^{* * *}: \mathrm{p}<0.001$ IV-EIA : type IV collagen, LM-EIA : laminin, Ch. E. : cholinesterase, Creat. : creatinin, FBS: fasted blood sugar, Plt.: platelet 
4. 断酒後の血清 $\mathrm{hHGF}$ 值の変動と, 各時点におけ る血清 hHGF 值および各種線維化マーカー值と Knodell の肝線維化のスコアーとの相関

入院前日まで飲酒していた症例で断酒 8 週間後まで 経過の追えた10例(LC：3例, LF：4例, AH：1例, NSR : 2 例)につき, 血清 $\mathrm{hHGF}$ 值の変動を観察する と, 入院時: $0.619 \pm 0.399 \mathrm{ng} / \mathrm{ml}, 2$ 週後: $0.505 \pm$ $0.292,4$ 週後: $0.457 \pm 0.217,8$ 週後: $0.350 \pm 0.167$ と次第に低下した。.また症例毎の検討でも，入院時は LF の 1 例を除き異常高值を示したが，8週後では LC の 2 例を除き，正常範囲内まで低下した (Fig. 3). 血 清総ビリルビン, GOT, GPT, $\gamma$-GTPなどの肝機能 検查値や, PIIIP, HA を除く IV.C, ラミニンなどの肝 線維化マーカー値，それにCDT 值も断酒後漸次低下 した.また各時点における血清 hHGF 值および各線維 化マーカー值と, 肝生検による肝線維化の程度 (Knodell の線維化のスコアー) との相関を見ると，血 清 hHGF 值は, 入院時 $\mathrm{r}=0.877(\mathrm{p}<0.001), 2$ 週後 : $r=0.794(p<0.01), 4$ 週後: $r=0.743(p<0.05)$, 8 週後 : $r=0.723(p<0.05)$ といずれの時点でも肝線 維化の程度と有意な正の相関を認め, 特に断酒直後の 入院時で良好であった.この血清 hHGF 值と Knodell の線維化スコアーとの間にみられた相関は, LM-EIA, LM-RIA，7S-RIA 值が線維化のスコアーとの間に示 した相関とほほ同等であり, かつ PIIIP や HA 以上の 良好な相関であった(Table 3). CDT 值はいずれの時

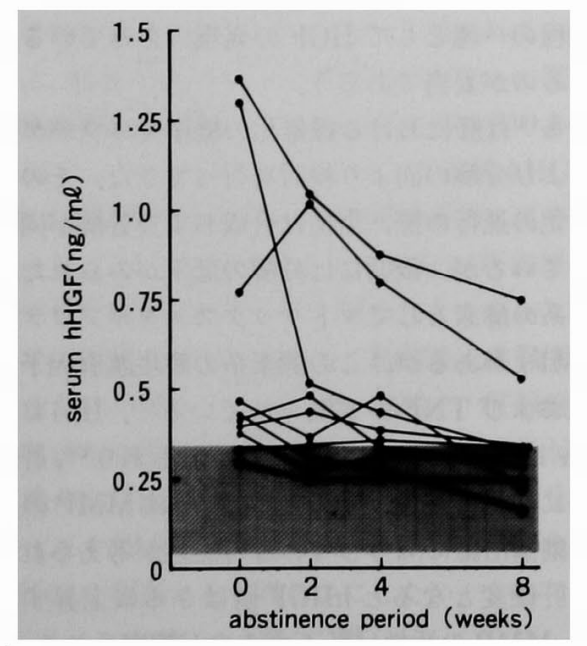

Fig. 3 Changes of serum level of hHGF in patients with alcoholic liver disease after abstinence. Shadow area shows normal range (mean $\pm 2 \mathrm{SD}$ ).
点においても肝線維化とは相関が認められなかった.

\section{5. 断酒後の血清 hHGF 値と肝線維化マーカー値と の相関}

断酒後 $0,2,4,8$ 週のそれぞれの時点における 血清 $\mathrm{hHGF}$ 值と各種線維化マーカー值との相関をみ ると,いずれの時点においても良好な相関が認められ たものは，LM-RIA およびLM-EIA であった（Table 4). 7S-RIA, PIIIP とは 0,2 週において, また HA とは 0,4 週において弱い相関が認められたのみで あった。CDT とは有意な相関が認められなかった。 ま た血清 $\mathrm{hHGF}$ 值と各種線維化マーカー値との各時点

Table 3 Correlation efficiency of various fibrotic markers against hepatic fibrosis (Knodell's score).

\begin{tabular}{l|l|l|l|l}
\hline $\begin{array}{c}\text { Abstinent } \\
\text { weeks }\end{array}$ & $0 \mathrm{w}$ & $2 \mathrm{w}$ & $4 \mathrm{w}$ & $8 \mathrm{w}$ \\
\hline hHGF & $0.877^{* * *}$ & $0.794^{* *}$ & $0.743^{*}$ & $0.723^{*}$ \\
7S-RIA & $0.681^{*}$ & $0.743^{*}$ & $0.795^{* *}$ & $0.754^{*}$ \\
LM-EIA & $0.792^{* *}$ & $0.776^{* *}$ & $0.831^{* * *}$ & $0.824^{* * *}$ \\
LM-RIA & $0.762^{*}$ & $0.852^{* * *}$ & $0.818^{* * *}$ & $0.821^{* * *}$ \\
PIIP & $0.656^{*}$ & $0.658^{*}$ & 0.318 & 0.323 \\
HA & 0.560 & 0.472 & $0.713^{*}$ & $0.663^{*}$ \\
CDT & 0.265 & 0.463 & 0.606 & 0.475 \\
\hline
\end{tabular}

$n=10, *: p<0.05,{ }^{* *}: p<0.01,{ }^{* * *}: p<0.001$

hHGF : human hepatocyte growth factor, 7S-RIA : type IV collagen $7 \mathrm{~S}$ measured by RIA, LM-EIA : laminin measured by EIA, LM-RIA : laminin measured by RIA, PIIIP : type III procollagen aminopeptide, HA : hyaluronic acid, CDT : carbohydrate-deficient transferrin

Table 4 Correlation efficiency of hHGF against various fibrotic markers at each point after abstience.

\begin{tabular}{l|c|l|l|l}
\hline $\begin{array}{c}\text { Abstinent } \\
\text { weeks }\end{array}$ & $0 \mathrm{w}$ & \multicolumn{1}{|c|}{$2 \mathrm{w}$} & \multicolumn{1}{|c|}{$4 \mathrm{w}$} & $8 \mathrm{w}$ \\
\hline 7S-RIA & $0.787^{* *}$ & $0.729^{*}$ & 0.595 & 0.473 \\
LM-EIA & $0.828^{* *}$ & $0.833^{* *}$ & $0.925^{* * *}$ & $0.800^{* *}$ \\
LM-RIA & $0.923^{* * *}$ & $0.886^{* * *}$ & $0.950^{* * *}$ & $0.782^{* *}$ \\
PIIIP & $0.739^{*}$ & $0.658^{*}$ & 0.522 & 0.431 \\
HA & $0.679^{*}$ & 0.447 & $0.850^{* *}$ & 0.372 \\
CDT & -0.268 & 0.389 & 0.408 & 0.483 \\
\hline
\end{tabular}

$n=10, *: p<0.05, * *: p<0.01,{ }^{* * *}: p<0.001$

7S-RIA : type IV collagen 7S measured by RIA, LM-EIA : laminin measured by EIA, LM-RIA : laminin measured by RIA, PIIIP : type III procollagen aminopeptide, HA : hyaluronic acid, CDT : carbohydrate-deficient transferrin 
での変化率の相関をみると，2週目はいずれも相関が 認められなかったが, 4 週目で LM-RIA 值 $(r=0.736$, $\mathrm{n}=10, \mathrm{p}<0.02)$ と PIIIP 值 $(\mathrm{r}=0.668, \mathrm{n}=10, \mathrm{p}<$ 0.05) は hHGF 值と有意な正の相関を示した。また 8 週目では LM-RIA のみが相関傾向 $(\mathrm{r}=0.607, \mathrm{n}=10$, $\mathbf{p}<0.1)$ を示した。

\section{考案}

血清 hHGF の測定キットが出来, 各種肝疾患におい て測定されてきているが，末だアルコール性肝疾患に おける測定については報告がみられない。今回著者ら は肝生検を施行し得たアルコール依存症者のうち， $\mathrm{HBS}$ 抗原, $\mathrm{HCV}$ 抗体のいずれもが陰性の症例を対象 とし, 肝生検時の血清 hHGF 值を測定した.その結果, ウイルス性肝障害と同様, 各種アルコール性肝疾患に おいても血清 hHGF 值は健常群より有意な高値を示 していた。特にアルコール性肝硬変症は，ウイルス性 肝硬変と同程度 ${ }^{83}$ の高值を示した。しかしウイルス性 肝障害と異なり，断酒直後より 8 週間後まで継続的に 経過を追うと，アルコール性肝障害ては断酒により全 例その值は漸次低下し，8週後には断酒直後に高值を 示した症例を除き正常範囲まで低下した。

また今回著者らは，肝生検組織所見と血清 hHGF 值 との対比を行った。最近 Shiota ら ${ }^{12}$ は immunoradiometric assayによる血清 hHGF 測定法を開発 し,ウイルス性慢性肝炎㭧者における血清 hHGF 値と HAI スコアーとの相関について検討し，両者の間に有 意の相関を認め，さらに4つのカテゴリーの中で necrosis と fibrosisのカテゴリーにおいても血清 hHGF 値と有意の相関を認めたと報告している，著者らも同 様に Knodell ${ }^{109}$ の HAI スコアーと血清 hHGF 値との 相関について検討を行ったが, Shiotaらの成績と一部 一致し，一部異なっていた，即ち著者らの検討では血 清 hHGF 值は HAI スコアーおよび fibrosis のスコ アーとの間で有意な相関を示したが, necrosis との間 では有意な相関を示さなかった．血清 hHGF 值とnecrosisの程度との相関に関する著者らと Shiota らの 成績の違いは，対象がアルコール性肝疾患とウイルス 性慢性肝炎とで異なるためとも考えられるが，今後更 に検討を要すると思われる。

さらに今回著者らは，アルコール性肝障害に特徵的 にみられる dense fibrosis ${ }^{11}$ の程度とも検討を行い, 血 清 hHGF 值との間には有意の正の相関を観察した。ウ イルス性慢性肝炎のみならず，アルコール性肝障害で も, 血清 hHGF 值と肝線維化の程度との間に相関が認
められることを明らかにした。

最近肝線維化の程度を知る検查法 ${ }^{23}$ として血清IV型 コラーゲン (IV-EIA および7S-RIA)，ラミニン (LM. EIA 捛よびLM-RIA)，III型プロコラーゲンペプチド (PIIIP)，ヒアルロン酸 (HA) などが報告されている が, 今回これらの検查值と血清 hHGF 值との相関につ いても検討を行った，その結果，肝生検時の 49 例では 血清IV型コラーゲン測定法のひとつである IV-EIA 值 と，血清ラミニンの測定法のひとつである LM-EIA 值 のいずれとも良好な正の相関を示し，また断酒後の経 過を追った10例では7S-RIA, LM-EIA，LM-RIA， PIIIP, HAのいずれの檤とも，各時点で有意な正の相 関を認めた。このうち血清ラミニン值とはいずれの検 查法 (LM-EIA，LM-RIA)においても断酒後 8 週目ま で各時点において非常に良好な相関を示した。

この様に血清 hHGF はアルコール性肝障害におい て肝線維化となんらかの関保があることが示された。 HGF は主に上皮系の細胞を標的として細胞増殖の調 節のほか, 細胞運動性促進作用 (scatter factor) やコ ラーゲンゲル中での管腔構造誘導作用を示すことが明 らかにされている ${ }^{14)}$. 最近では HGF の生理機能とし て肝再生だけでなく堅臟や肺を含め組織損傷後の修 復・再生に関与しているという考えが有力となってき ている(4).これらの所見より,アルコール性肝障害にみ られた血清 hHGF 值と肝線維化の程度との相関は, 両 者の間の直接的なつながりで㹥なく，むしろ慢性肝障 害の際に生ずる種々の反応のうち, 線維化扔よび創傷

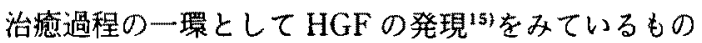
と考えるのが妥当であろう。

著者らは恬における線維化の機序をコラーダンの 合成および分解の面より検討を行ってきた，その結果 肝線維化の進行の際, 当初は合成および分解が同時に 六進しているが，後期には分解の低下がみられた。こ の分解系の䤃素としてマトリックスメタルプロテアー ぜ (MMP) があるが，この醉素系の産生誘導因子とし てIL-1およびTNF- $\alpha$ が知られている17. IL-1および TNF- $\alpha$ は HGF の産生誘導の因子でもあり ${ }^{18}$, 肝線維 化過程における血清 hHGF 值の上昇は MMP の上昇 と共に創傷治撚に関与している可能性が考えられる。 しかし肝硬変となると hHGF 值はさらに上昇するの に対し,MMP の活性は低下寸るのが観察される.従っ てこの解離については HGF の肝での排泄・異化の低 下によるものかさらに検討が必要であろう。

アルコール性肝障害で観察した血清 hHGF 值の上 
昇は，産生の元進と排浛 - 異化の低下によるものが考 えられる. ウイルス性慢性肝炎での血清 hHGF 值の上 昇は，肝における hHGF の産生の元進によるものと考 えられている.そして,肝内の産生細胞として Kupffer 細胞, 類洞壁内皮紏胞, 伊東細胞が知られている た最近では七ト多核白血球が報告されている201.一方 HGF の排泄-異化の低下については，劇症肝炎や肝硬 変症でみられることが報告されている。これらの所見 より今回著者らが観察したアルコール性肝障害での血 清 hHGF 值上昇の機序を考える場合, 産生の亢進とし てはアルコール性肝资などにみられる多核白血球の漫 潤,またアルコール性肝障害の線維化に関連して増加 する伊東細胞の関与，それに分解・排泄の低下として は肝硬変の存在等が考えられる.しかし多核白血球に 関しては今回の検討ではアルコール性肝炎でさほど高 值を呈さず，その関与は明らかでなかった。しかし症 例数が 3 例と少なく，きらに症例を増やして検討する 予定である.また hHGF 麾生細胞に関しては今後, 免 疫組織化学的な手法や in situ hybridization 法などの 遺伝学的手法の检討により明らかになるであろう。

以上 $\mathrm{HGF}$ の産生から排泄・異化に至る過程を考慮 に入れ、アルコール性肝疾患において血清 hHGF 值が 旰線維化と関連すると考えられる機序を述べた。しか し,この他 Aldana ら ${ }^{15}$ が述べているように, HGF が 作用する際のリセプターが慢性肝障害で低下している ために血清 hHGF が高值を示すという機序も存在す る可能性も見逃せない。従ってこの点についても今後 さらに明らかにされねばならないと思われる。いずれ にせよ, 血清 hHGF 値と肝線維化の程度との関連は, 創傷治癒過程の一環として考えるのが妥当であるう。

今回アルコール性肝疾患において血清 hHGF 值を 測定し，肝線維化の程度との相関が非常に良好であっ たことにより，血清 hHGF 值の測定が肝線維化マー カーとして有用ではないかと思われた。しかし前述の 如くその上昇汶わずかであり，断酒後正常範囲内にお さまるものが多く, sensitivity が悪く, 肝線維化マー カーとはなり得ないと思われた。たた肝疾患が慢性で ある場合には経過を追うことにより, 肝線維化の進行 をチェックできる可能性はあるであろう。今後 pro. spectiveな調查により明らかにしたい.

\section{文献}

1) Moolton FL, Bucher NLR: Regeneration of rat liver: Transfer of humoral agent by cross circulation. Science 158: 272-274, 1967
2) Nakayama H, Tsubouchi H, Gohda E, et al : Stimulation of DNA synthesis in adult rat hepatocytes in primary culture by sera from patients with fulminant hepatic failure. Biomed Res $6: 231-237,1985$

3) Gohda E, Tsubouchi $H$, Nakayama $H$, et al : Human hepatic growth factor in plasma from patients with fulminant hepatic failure. Exp Cell Res 166:139-150, 1986

4) Gohda E, Tsubouchi H, Nakayama H, et al : Purification and partial characterization of hepatocyte growth factor from plasma of a patient with fluminant hepatic failure. J Clin Invest $81: 414-419,1988$

5) Tsubouchi H, Hirono S, Gohda E, et al : Clinical significance of human hepatocyte growth factor in blood from patients with fulminant hepatic failure. Hepatology 9:875-881, 1989

6) Tsubouchi H, Hirono S, Gohda E, et al : Human hepatocyte growth factor in blood from patients with fulminant hepatic failure. I. Clinical aspect. Dig Dis Sci 36:780-784, 1991

7) Tsubouchi H, Niitani $Y$, Hirono $S$, et al : Levels of the human hepatocyte growth factor in serum of patients with various liver diseases determined by an enzyme-linked immunosor. vent assay. Hepatology $13: 1-5,1991$

8）武蔵泰敏，河合 忠, 俈藤俊一, 他: 肝疾患患者に おける血清ヒト肝細咆增殖因子(hHGF)レベル測

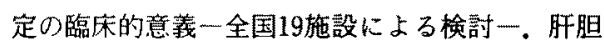
膵 $25: 541-549,1992$

9）高田 昭, 两平雅彦、太田康莘, 他: アルコール性 肝障害に対する新しい診断基準試案の提案. 肝臓 $34: 888-896,1993$

10) Knodell RG, Ishak KG, Black WC, et al : Formation and application of a numerical scoring system for assessing histological activity in asymptomatic chronic active hepatitis. Hepatol 1: $431-435,1981$

11）中野雅行, 中沢 功, 弓野明彦, 他：アルコール性 肝線維症の形態学的特徵一特に非 $\mathrm{A}$ 非 $\mathrm{B}$ 肝炎と 比較して.「アルコール代謝と肝 Vol て」アルコー ル代謝と肝研究会編，東洋書店，東京，1988，p203 $-211$

12) Shiota G, Okano J, Kawasaki H, et al: Serum hapatocyte growth factor levels in liver dis- 
eases: Clinical implications. Hepatology 21 : $106-112,1995$

13）和田則仁，丸山勝也，荒井正夫，他：肝硬変と間貿。 Biomedical Perspectives 3 : 37-45, 1994

14) Goldberg ID, Rosen EM: Hepatocytes Growth Factor-Scatter Factor (HGF-SF) and the C-Met Receptor, Birkhauser V'erlag, Basel, 1993

15) Aldana PR, Goerke ME, Carr $S C$, et al: The expression of regenerative growth factors in chronic liver injury and repair. J Surg Res 57 : $711-717,1994$

16）丸山勝也, 岡崎 僅:アルコールと肝線維化一ア ルコールによるコラーダン代謝に及ぽす影智。医 学のあめ $154: 921-925,1990$

17）岡崎 䰻, 荒井正夫, 和田剧仁, 他：Matrix Metalloproteinases の遗伝子発現.「肝細胞の遺伝子, 肝
細胞マトリックス, 類洞壁細胞」, 箱根シンポジウ 公記録刊行会編, 中外医学社, 東京, 1995, p7683

18) Tamura M, Arakaki N, Tsubouchi $H$, et al : Enhancement of human hepatocyte growth fac. tor production by interleukin-1 alpha and 1-beta and tumor necrosis factor-alpha by fibroblasts in culture. J Biol Chem 268:8140-8145, 1993

19）松本邦夫：HGF の構造，多栐な生物活性とその発 現調節。実験医学 $11: 1111-1119,1993$

20）坪内博二, 弘野修一, 石野田与至宏, 他：肝細胞增 殖因子(HGF)の遺伝子発現.「肝細胞の遺伝子, 肝 細胞マトリックス, 類洞壁細胞」, 箱根シンポジウ 么記録刊行会編, 中外医学社, 東京, 1995, p21一 26

\title{
Measurement of serum human hepatocytes growth factor (hHGF) in patients with alcoholic liver disease in relation to hepatic fibrosis
}

\author{
Katsuya MARUYAMA "), Isao OKAZAKI ${ }^{2)}$, Norihito WADA ${ }^{2)}$, \\ Hisao TAKahashi ${ }^{11}$, Keiji OKUYama ${ }^{1)}$, Akira YokoYama ${ }^{12}$, \\ Masayuki NAKANO ${ }^{3 !}$ and Hiromasa ISHII)
}

We measured serum levels of human hepatocyte growth factor (hHGF) at the time of liver biopsy in patients with various types of alcoholic liver disease who were negative for $\mathrm{HBs}$ antigen and $\mathrm{HCV}$ antibody and underwent liver biopsies. Compared to normal populations in the literature, patients with each type of disease excluding fatty liver and alcoholic hepatitis for which there were few cases showed significant high values. The value for liver cirrhosis patients was significantly higher than those for all other diseases except fatty liver. Serum hHGF showed a good correlation only with the degree of hepatic fibrosis among histological finding. Serum hHGF values showed a good positive correlation with values of serum fibrotic markers such as type IV collagen and laminin. Serum hHGF levels dropped after abstinence, but there was a significant correlation with the severity of hepatic fibrosis and serum levels of laminin at all times. Serum hHGF was assumed to show some relation with hepatic fibrosis.

1) Clinical Research Unit. Kurihama National Hospital (Kanagawa)

2) Department of Community Health, Division of Community and Environmental Health. School of Medicine,

Tokai University (Kanagawa)

3) Research Center for Pathogenic Fungi and Microvial Toxicosis, Chiba University (Chiba)

4) Department of Internal Medicine, School of Medicine, Keio University (Tokyo) 